\title{
Selvets teknologier, e-læring og neo-traditionel islamisk selvudvikling
}

\author{
Af Kasper Mathiesen
}

\begin{abstract}
This article addresses the ways in which contemporary Muslims make use of the Internet to establish new kinds of communities of practice and learning associated with the technologies of the self and Islamic self-cultivation. Within the confines of the new communities the fundamental aspiration and ambition is similar to that of the classical tradition, but the non-physical framework simultaneously yields new possibilities and new challenges in regard to learning. The didacticaltheoretical point of departure of the analysis is above all the social psychological learning perspective developed by Lave and Wenger. The analysis is based on a representative example of elearning from the Islamic learning portal Sunnipath/Qibla and is especially related to the transnational and globally influential Bâ'alawiyya order, here construed as an exponent of a broader neo-traditional Islamic current. Patterns of learning and of learning within the confines of the ecommunity of practice are compared with more traditional and physically constituted contexts of situated learning through participation in intensified Islamic practices of self-cultivation. On the basis of observation, participation and interview material from both types of contexts the learning patterns of the new virtual communities of practice are analysed with an emphasis on presence and motivation in regards to learning.
\end{abstract}

\section{Introduktion}

Studiet af islam og islamiske gruppers tilstedeværelse og brug af internettet er et stadigt voksende forskningsfelt ${ }^{1}$. Hidtil har forskningen især fokuseret på, hvorledes internettet bruges af muslimer til at skabe transnationale netværk og til at søge islamisk vejledning i beslutningssager; hvordan nettet er med til at udfordre og forandre islamiske autoritetsstrukturer og identiteter, og hvordan det bruges som mobiliseringsinstrument af f. eks islamistiske bevægelser (Bunt 2003). Andre har peget på, at nettet er en ny offentlig sfære, der letter spredningen af, og adgang til, fortolkningsmodaliteter og islamiske udtryk, der hidtil har været marginaliseret, og at nettet således har en afmonopoliserende og liberaliserende effekt (Anderson 2003). Bunt peger på, at nettet på grundlæggende vis er med til at ændre mønstre for islamisk informationssøgning og videnstilegnelse uden dog at komme nærmere ind på didaktiske og læringsteoretiske aspekter ved dette. Han nævner at;

...the Internet has supplemented, and in some cases supplanted, traditional approaches to Islamic knowledge management and dissemination. The access to Islamic texts and religious

(C) Forfatteren og Tidsskrift for Islamforskning, ISSN 1901-9580, publiceret 27-4-2012 
opinion, for example, crosses boundaries that earlier generations faced. The traditional concept of "sitting at a scholar's feet" to acquire knowledge about Islam still exists. But it now has a digital equivalent (Bunt 2009: 15).

Præcis hvad denne digitale pendant indebærer rent læringsmæssigt er et tema, der hidtil ikke er blevet berørt. I følgende analyse undersøges internetbaserede modstykker og supplementer til den traditionelle (sufi)-islamiske læringspraksis ud fra et didaktisk-teoretisk perspektiv og en hypotese om, at e-læringsproduktet, isoleret set, vil adskille sig markant fra traditionelle læringsprodukter som følge af den internetbaserede læringskonteksts anderledes struktur og interaktion. Adgangen til islamisk viden er i nutiden ganske vist blevet lettet enormt pga. især internettet, og det er blevet muligt at etablere interaktive læringsfællesskaber og halaqa'er (læringscirkler) på tværs af store fysiske afstande og landegrænser. Særligt i den islamiske sufitradition (tasawwuf) anses selve samværet (suhba) med den åndelige mester (shaykh) og de øvrige spirituelle aspiranter imidlertid for at være en nøgle til at gennemgå den dybe personlige, åndelige og moralske selvudvikling eller renselse (tazkiyyat al-nafs), der er den islamiske traditions spirituelle aspiration. For at opnå den intimitet med Gud (qurb min Allah) og den eksperimentelle mystiske indsigt (ma'rifa billah), som murîden (Den spirituelle novice eller, bogstaveligt talt, den, der søger Gud) stræber efter, må han eller hun først og fremmest søge viden om Guds åbenbarede vejledning til mennesket ( $\mathrm{ilm}$ ), implementere denne viden i sit liv ( 'amal) og søge selskab med og vejledning (irshâd) hos dem der har vandret vejen mod Gud (al-sayr ilâ Allah) og kender dens udfordringer.

Det undersøges, hvorledes den religiøse læring og suhba manifesterer sig i nutidens virtuelle islamiske læringsmiljøer, med udgangspunkt i en kontekst, der har relation til bâ'alawiyya-ordnen og den islamiske online-læringsportal Sunnipath/Qibla (se nedenfor). Dette eksempel er valgt på basis af en række forhold: (1) Ba'alawiyya-ordnens høje grad af mobilitet og dens lange tradition for interkontinentale og transnationale sufi-relaterede lærings- og missionsnetværk (Bang 2000; Freitag 1999; Freitag and Clarence-Smith (eds.) 1997; Ho 2006) er en vigtig model og samtidig et $i$ forvejen eksisterende strukturelt fundament for neo-traditionel islams udbredelse i nutiden (Kotb 2004). (2) Det eksemplificerer det gensidigt anerkendende forhold og endda udbredte samarbejde mellem forskellige ordner og islamiske lærde af forskellig baggrund og relativt varierende opfattelser, der kendetegner den neo-traditionelle opblomstring i nutiden (Geaves 2006; Stjernholm 2011). (3) Det eksemplificerer det bredt funderede, som regel ikke-sekteriske al-Junayd (d. 910) og (C) Forfatteren og Tidsskrift for Islamforskning, ISSN 1901-9580, publiceret 27-4-2012 
al-Ghazâlî (d. 1111) funderede sufi-islamiske etos (Karamustafa 2007), der grundlæggende kendetegner både bâ'alawiyya-ordnen og neo-traditionel islamisk sufisme. (4) Læringsportalen Sunnipath/Qibla er både pioner og en ledende global eksponent for den type islamisk e-læring, der kendetegner neo-traditionel islam. (5) Eksemplet åbner op for studiet af relationen mellem de islamiske e-læringsmiljøer og de fysisk-funderede praksis- og læringsmiljøer, de udspringer af.

Inden selve analysen udfoldes, er det imidlertid nødvendigt med en kritisk diskussion omhandlende de teoretiske grundrammer, analysen tager udgangspunkt i, og de tre teoretiske hovedområder der søges sammenbundet: Henholdsvis begrebet 'selvets islamiske teknologier', det læringsteoretiske perspektiv og begrebet 'traditionel islam'.

\section{Selvets islamiske teknologier og den religiøse læring}

Michel Foucaults begreb technologies de soi, selvets teknologier, betegner de praksisser og metoder $\mathrm{i}$ en given epoke eller kulturssfære som individer, der befinder sig inden for disse, kan benytte til at “drage omsorg for selvet'. Ved hjælp af selvets teknologier kan mennesket udvikle viden om og tage magt over sig selv og forme selvet, bearbejde det kognitivt, kropsligt, åndeligt og moralsk, i henhold til de personlighedsmæssige, religiøse eller eksistentielle idealer, kulturen udstikker (Foucault 1988). Analysen af disse selvets muligheder for magtudøvelse i forhold til sig selv udspringer hos Foucault af studiet af klassisk græsk og førmoderne kristen praksis, men kan ligeledes bruges til at undersøge ikke-vestlige former for selvbearbejdelse og de muligheder, metoder og idealer for personlighedsdannelse og selvanskuelse disse indbefatter (Boudreau 1992; Mahmoud 2005).

For at indtænke selvets teknologier i en normativ sunni-muslimsk kontekst er det nødvendigt at have en række forhold for øje, som kendetegner den islamiske tradition. (1)

Selvbearbejdningsmetoderne vil være uløseligt forbundet til åbenbaringshændelsen, det Muhammad Arkoun kalder le fait quranique, og den mangel i det dominerende islamisk-religiøse imaginaire på principiel analytisk adskillelse mellem denne og traditionens udkrystallisering og nedfældelse i klassisk tid, le fait islamique, som Arkoun har påpeget (Benzine 2004). Det indebærer at sunnimuslimsk selvudviklingspraksis, omend den har en dynamisk tilblivelseshistorie, reelt udgør et stort set stabilt kanoniseret repertoire af teoretisk og praktisk viden ('ilm), som symbolsk opsummeres i koranen og sunnaen, men reelt også indbefatter de religiøse videnskaber ( 'ulûm al-dîn). Islamisk

(C) Forfatteren og Tidsskrift for Islamforskning, ISSN 1901-9580, publiceret 27-4-2012 
tradition forstås således her, delvist inspireret af Talal Asad, som de diskurser og argumentations/forståelsesmoduser, der hævder at repræsentere korrekt praksis og fortolkning, som fungerer som reservoir eller fundament for skiftende tiders brug, nytænkning og omstrukturering i henhold til forandrede magtrelationer, behov og interesser (Asad 1986) og som kognitivt ikke opfattes som væsensforskelligt fra Guds direkte åbenbarede foreskrifter. (2) Individets tro på, at denne viden er sand $\mathrm{i}$ absolut forstand, og dets systematiske tilegnelse og internalisering af den er en paradigmatisk forudsætning for, at han kan indtræde på den efterlivets vej (tarîq al-âkhira) som den sunnitiske tradition, bl.a. i en af dens mest indflydelsesrige manifestationer, al-Ghazâlîs Ihyâ' 'ulûm al-dîn, definerer som selve religionens telos; at forberede sjælen på dets møde med Gud (Gianotti 2011). Der er således et dialektisk forhold mellem de processer, hvorved denne verdensopfattelse kultiveres og internaliseres, og de teknologier til selvbearbejdning som traditionen tilbyder. Disse processer bør derfor i sig selv anskues som elementer af selvets teknologier, fordi de etablerer det rum eller den livsverden, hvor selvets teknologier udfolder sig. (3) Selvbearbejdningen udfoldes inden for rammerne af en teologi og en livsverden, hvis centrale akse er en absolut alvidende og almægtig Gud (tawhîd), og selvbearbejdningen forstås derfor som en guddommeligt tildelt oplysnings-/renselsesproces (tanwîr/tazkiyya), hvor Gud gradvist afslører (kashf) sandheden i absolut forstand (haqîqa), herunder sandheden om individets fuldstændige hjælpeløshed (faqr) i forhold til at handle for egen frelse (Schimmel 1975; Wilcox 2011).

Hvert af disse tre punkter rejser en række teoretiske problemstillinger, som jeg i denne artikels kontekst ikke kan gå dybere ind i. Udover de temaer der er relateret til islam - især normativitet, heterodoksi og ortodoksi, tradition og imaginaire, åbenbaring og kanonisering - tænkes bl.a. på forholdet mellem kropslig praksis og selvbearbejdning; temaet kosmologi, eskatologi og selvteknologiernes teleologi; ritualets funktion i forhold til bearbejdningen af selvet; problemstillinger relateret til agens og teologi og endelig selve fænomenerne overbevisning og religiøsitet. Flere af disse teoretiske udfordringer relateret til bearbejdningen af selvet diskuterer Foucault og andre, der i hans fodspor har beskæftiget sig med kultiveringen af selvet, i andre religiøse kontekster, herunder nutidige muslimske (Asad 1993; Hirschkind 2006; Mahmoud 2005; Pinto 2010). Men her er det kun muligt at introducere nogle af de temaer, som instrumentaliseringen af Foucaults ideer i en islamisk kontekst åbner for og derigennem give et billede af nogle af de antropologiske og erkendelsesmæssige temaer teorien rejser. 
Et aspekt man kan kritisere ved Foucaults analyse af individets muligheder for selvbearbejdelse er, at selvets teknologier i hans fremstilling bliver temmelig statiske størrelser. De læringsprocesser hvorigennem det enkelte individ først tilegner sig og begriber teknologierne, i tiltagende grad bliver i stand til at mestre dem for afslutningsvist, ideelt set, at have gennemgået en bearbejdelse af selvet så det ønskede ideal opnås, berører Foucault ikke. Ydermere synes forholdet mellem kollektiv og individ i selvbearbejdningen og i forhold til succesfuldt at opnå mestring af selvet og selvets teknologier at forblive næsten uberørt. Dog nævner han at specifikke selvteknologier stammer fra bestemte sekter eller filosofiske samfund og kommer ind på betydningen og funktionaliteten af forholdet mellem mester og elev (Foucault 1988).

Det skulle fremgå af ovenstående fremstilling, at min indtænkning af selvets teknologier i en sunnimuslimsk kontekst til dels gør det muligt at nedbryde den dikotomi mellem sufisme og islam, som har præget store dele af den formative vestlige islamforskning (Christman 2008). Ganske vist er den terminologi der giver individet mulighed for at overskue, begrebsliggøre og forstå sin religiøse praksis som en selvbearbejdning ofte relateret til det man forbinder med sufisme, hjertets fiqh (fiqh al-qalb/'ilm ahwâl al-qulûb), videnskaben om den absolutte sandheders afsløring ('ilm almukâshifa) og videnskaben om det indre ('ilm al-bâtin) Men samtidig er den praksis, ('ilm al$m u$ 'âmilât) der foreskrives, mestendels identisk med almindelig islamisk praksis eller er en intensivering af den eller bestemte elementer af den (Gianotti 2011).

Denne artikels hovedsigte er at analysere de muligheder for læring af selvets teknologier internettet giver. Analysen fokuserer overordnet på spændingen mellem tilegnelsen af viden ('ilm) og etableringen af praksis ('amal) og på de ovennævnte forandrede læringskonteksters indvirkning herpå. Som sådan undersøges læringen ved at sammenligne den med mere traditionelle og fysiskkonstituerede islamiske læringskontekster. Som læringsteoretisk analyseperspektiv benyttes især Jean Lave og Etienne Wengers socialpsykologiske læringsforståelse. Da denne læringsteori udgør den overordnede ramme indenfor hvilken analysen skal læses, er det nødvendigt kritisk at gennemgå teoriens grundelementer.

Lave og Wenger repræsenterer et socialkonstruktivistisk læringssyn, der dels lægger vægt på, at læring er et konstituerende grundelement i al social aktivitet, og dels på at læring er interrelationel og situeret inden for rammerne af praksisfællesskaber. En central kontekst for denne forståelse af

(C) Forfatteren og Tidsskrift for Islamforskning, ISSN 1901-9580, publiceret 27-4-2012 
læring er Bourdieus teori om handling og praksis og særligt habitus-begrebet (Bourdieu 1977). Hovedbegrebet legitimate peripheral participation (legitim perifær deltagelse - LPD) bruges til at forklare, hvordan læringen i dette bredere situerede perspektiv foregår. Gennem aktiv deltagelse i bestemte praksisfællesskabers specifikke praksisser tilegner individet sig et bestemt felts habitus samt dets diskurser og værdier. Læringen findes altså i praksissen og sker igennem interaktionen med mere rutinerede personer eller udøvere, der i højere grad besidder den viden og ekspertise, praksisfællesskabet defineres af. Det er et perspektiv, der bl.a. læner sig op af fænomenet mesterlære uden imidlertid at være helt identisk med det. Grundlæggende forstås læring ikke som transmissionen af en bestemt videnspulje om verden fra et individ til et andet, selvom det anerkendes at subjektive kognitive forandringer er et element i læringsprocessen. Snarere anskues læring som de processer, hvorigennem en persons identitet, selv- og verdensopfattelse, praksis og status i forhold til bestemte praksisfællesskaber ændres i en bevægelse fra at være perifær nytilkommen til at være fuld deltager. Perspektivet lægger vægt på en holistisk forståelse, der involverer hele personen og som fokuserer på “...activity in and with the world; and on the view that agent, activity, and the world mutually constitute each other." (Lave og Wenger 1991: 33).

Centralt for den situerede læring er begreberne adgang (access), gennemsigtighed (transparency) og teknologier (technologies). Det legitime i LPD beskriver niveauet af adgang til praksisfællesskabets ressourcer, information, samvær med andre medlemmer og dets forskellige aktiviteter, hvilket er konstituerende for den situerede læring. Adgang til deltagelse er en forudsætning for, at individet kan bevæge sig fra en position som lærling til at blive fuldt deltagende medlem af praksisfællesskabet. Ligeledes er adgang fundamental for at personen kan tilegne sig læringsfællesskabets centrale teknologier; dets metoder, praksisser, redskaber, diskurser og strukturer. LPD er med til at begrebsliggøre en læringsproces, hvorigennem gennemsigtigheden af praksisfællesskabets teknologier forøges, og individet $\mathrm{i}$ tiltagende grad opnår forståelse for disse, bliver i stand til selv at mestre dem og ender med selv at kunne forholde sig som mester i forhold til ny LPD. Det er klart, at praksisfællesskabets struktur også som helhed transformeres, genforhandles og forandres i takt med, at disse interrelationelle læringsprocesser udfolder sig. Det er ligeledes klart at reproduktion og kontinuitet af praksisfællesskabet direkte afhænger af, i hvor høj grad det er i stand til at afstedkomme de processer som LPD som læringsteoretisk perspektiv omfatter. 
Et centralt element i LPD er den forståelse af sprog og sproglig praksis, som teorien udspringer af og indebærer. Sprog bruges som didaktisk redskab i LPD, men samtidig er tilegnelsen af praksisfællesskabets sproglige praksis essentiel for, at den identitetsforandrende bevægelse hen imod fuld deltagelse, som læringsperspektivet har i sin kerne, kan forløbe. Dette er vigtigt, fordi det udfordrer det traditionelle skel mellem teoretisk og praktisk læring. Overordnet set er produktionen af didaktisk diskurs en del af praksis snarere end at være en abstrakt repræsentation af praksis. Der skelnes således mellem at tale om, som teoretisk øvelse og at tale indenfor rammerne af en praksis, men begge elementer skal ses som former for praksis;

Thus the didactic use of language, not itself the discourse of practice, creates a new linguistic practice, which has an existence of its own. Legitimate peripheral participation in such linguistic practice is a form of learning, but does not imply that newcomers learn the actual practice the language is supposed to be about. (Lave og Wenger 1991: 108).

Det foreslås således grundlæggende, at miljøer for intensiveret islamisk selvbearbejdningspraksis kan anskues som praksis- og vidensfællesskaber, som er kendetegnet ved den situerede læring gennem LPD, som Lave \& Wenger har fremsat. Der er en høj grad af affinitet mellem de to teknologi-begreber introduceret ovenfor (hhv. Foucaults samt Lave og Wengers). Selvets islamiske teknologier må siges at være konstituerende teknologier for de praksisfællesskaber, der defineres ved intensiveret islamisk selvbearbejdningspraksis. Lave \& Wengers teknologi-begreb er imidlertid mere omfattende og indbefatter derudover også de øvrige teknologier, der kendetegner et praksisfællesskab, og som ikke, som i denne kontekst, umiddelbart har noget med selvbearbejdningen at gøre. Da forekomsten af sociale situationer, hvor der på et eller flere områder findes en niveauforskel i de involverede parters ekspertise, er nok til at LPD opstår, er læring, som modsætning til intenderet instruktion eller undervisning, konstituerende for al social aktivitet. Det indebærer, at læring altid foregår på uoverskueligt mange forskellige niveauer, og at al læring fundamentalt er kendetegnet ved gensidighed og forhandling. Det indebærer også, at langt fra al læring i disse miljøer for intensiveret islamisk praksis er islamisk i den forstand, at den afspejler islamisk tradition, som begrebet er forklaret ovenfor.

Som analytisk perspektiv er teorien om situeret læring gennem LPD bl.a. behjælpelig i forhold til at forstå, hvordan læringsproduktet kan være vidt forskelligt i praksisfællesskaber der ellers i teorien

(C) Forfatteren og Tidsskrift for Islamforskning, ISSN 1901-9580, publiceret 27-4-2012 
efterstræber det samme mål. Følgende fire spørgsmål diskuteres i nedenstående undersøgelse: (1) I hvilken grad kan man forvente, at opkomsten af e-læring og internetbaserede religiøse netværk har været med til at skabe typer af praksis- og læringsfællesskaber for islamisk selvbearbejdning, der afstedkommer læringsprodukter, der adskiller sig fra mere traditionelle konteksters læringsprodukter? (2) Hvordan adskiller læringen sig? (3) Hvilken rolle spiller de nye teknologier i transmissionen af islamisk praksis og viden, og hvordan er samspillet mellem de nye typer af praksisfællesskaber og den bredere læringskontekst i mere traditionelle fysisk-konstituerede praksisfællesskaber? (4) Hvordan motiveres de studerende til selvbearbejdning i elæringsfællesskabet?

\section{Al-tarîqa al-'Alawiyya og neo-traditionel islam}

Al-tarîqa al- 'alawiyya (kaldes også bâ'alawiyya-ordnen), er en sunni-muslimsk sufiorden (tarîqa), med rødder Hadramawt-regionen i det østlige Yemen. Betegnelsen refererer til Profetens efterkommere (pl. sâdah, sing. sayyid) gennem 'Ali og Fatima (Banû 'Alawî), som udgør kernen af ordnen. Ifølge traditionens genealogier forlod deres forfader, Ahmad bin 'Isâ al-Muhâdjir, Irak i det 10. århundrede som følge af politisk ustabilitet, forfølgelse og mistænkeliggørelse af ahl al-bayt, og slog sig ned i Hadramawt, hvor særligt byen Tarîm med tiden er blevet ordnens spirituelle hovedstad. Fra det 13. århundrede blev en anden af de legendariske 'Alawî-forfædre, al-Faqîh alMuqaddam initieret eller udnævnt (ilbâs khirqat al-tasawwuf) som officiel repræsentant for en orden, hvis silsila (spirituelle genealogi) går tilbage til Profeten og i sidste ende Gud, som opfattes som værende den egentlige skænker af den eksperimentelle mystiske indsigt (ma'rifa billah) som islamisk tasawwuf sigter imod (Al-Qushayri 1990; Schimmel 1975), gennem den store andalusiskmarokkanske shaykh Abu Madyan (1126-1198). Både denne linje og den ovennævnte blodlinje opfattes som havende spirituel karakter og indeholde guddommelig velsignelse (baraka). Ved sin initiering knækkede al-Faqîh al-Muqaddam ifølge den paradigmatiske fortælling sit sværd over sit knæ og indledte således en lang tradition for pacifistisk islam, der kendetegner bâ'alawiyya traditionen indtil nutiden.

Fra 1400-tallet har de profetiske efterkommere, herunder dem der var aktive inden for sufi-ordnen, været kendetegnet ved en høj grad af mobilitet og missionsiver, særligt på tværs af det Indiske Ocean. Fra Østafrika til Syd-øst Asien, ordnens numeriske kerneområder, kan man i dag finde transnationale multietniske netværk af populationer der er bevidste om at nedstamme fra Profeten 
og Hadramawt og om, at de er indbyrdes relaterede. Dette skyldes bl.a familiens udbredte brug af skrevne genealogier med et identitetsskabende og didaktisk tilsnit. Samtidig har regionen og særligt Tarîm, hvor de fleste af ordnens helgener ligger begravet, udviklet sig til at være et mytisk ophav for denne diaspora. Det har været almindeligt at vende tilbage dertil på pilgrimsrejser og for at søge islamisk viden, ligesom der har udviklet sig en tradition for at sende sine børn til området for at kultivere deres religiøsitet (Ho 2006). Imperietidens afslutning og nationalstaternes opkomst medførte en mistænkeliggørelse af transnationale identiteter som den, bâ'alawiyyerne havde kultiveret gennem århundreder. Under kommunismen i Sydyemen blev religiøse fællesskaber og autoriteter, herunder ikke mindst bâ'alawiyyerne, massivt undertrykt og religiøse institutioner lukket eller forbudt. Dette medførte en underminering af de profetiske efterkommeres magt og indflydelse og en transformation af deres tilhørsforhold og selvopfattelse (Ho 2006). Siden Yemens genforening og kommunismens fald er Hadramawt og Tarîm imidlertid genopstået som pilgrimsdestination og religiøst læringscenter bl.a med etableringen af flere nye skoler og universiteter. Disse modtager årligt tusindvis af elever på alle niveauer, profetiske efterkommere og andre, fra hele den islamiske verden (Knysh 2007). Internet og pan-arabisk satelit-TV, som befordrende for nye former for tilstedeværelse og mobilitet, har desuden spillet en stor rolle for ordnens udbredelse og aktiviteter. Dette ikke mindst i samspil med de profetiske efterkommeres ofte succesfulde socio-økonomiske og politiske integration i den nye diaspora i Golf-landene og Saudi Arabien (efter kommunismens opkomst i Sydyemen). Fra slutningen af 1990‘erne stod det klart, at bâ'alawiyya-ordnen så ud til at kunne blive central for en sunni-islamisk, tasawwuforienteret opblomstring. Denne opblomsting er siden blevet et ideologisk og religiøst modspil til 1980‘erne og 1990‘ernes dominerende strømninger islamisme, salafisme, reformisme og wahhabisme (Freitag 1999; Knysh 2001), sufismens ideologisk set argeste modstandere (Sirriyeh 1999). Samtidig har nogle af disse grupper i løbet af det 20. århundrede været medvirkende til at underminere den gunstige socio-økonomiske position og særlige religiøse status som de profetiske efterkommere nød godt af $\mathrm{i}$ store dele af den arabiske verden i hedengangne århundreder (AlSayyid Sabîh 2007; Pappé 2010).

Denne neo-traditionelle tasawwuf-orienterede sunnimuslimske strømning, hvoraf bâ'alawiyyerne kan siges at være en del, bruger ofte selvreferentielt betegnelsen traditional islam i det nordatlantiske område (Geaves, 2006; Stjernholm 2011) og har bredt sig på tværs af den islamiske verden særligt i løbet af de sidste to årtier. Forud for opkomsten af denne strømning ligger en

(C) Forfatteren og Tidsskrift for Islamforskning, ISSN 1901-9580, publiceret 27-4-2012 
omfattende post-kolonial idemæssig rekonstruktionsproces, hvorigennem den islamiske tradition eller arv (turâth), herunder tasawwuf-begrebet, er blev gentænkt, omdefineret og revurderet. Opgøret med de orientalistiske opfattelser, der gennem flere årtier havde indflydelse på opfattelsen af sufisme i den arabiske verden gennem det oversatte materiale, der brugtes i de statslige uddannelsesinstitutioner, er centralt for denne proces. Dette medførte en begrebsmæssig opsplittelse af tasawwuf-begrebet, således at den normative islamiske sufisme (al-tasawwuf al-islāmī) er blevet udskilt fra andre typer af sufisme, som indeholdes i den bredere arv og som følgelig opfattes som mere eller mindre illegitime og fremmede i en ortodoks islamisk kontekst: Nihilistisk sufisme (altasawwuf al-salb $\vec{\imath}$ ), der associeres med buddhisme og hinduisme; filosofisk sufisme (al-tasawwuf al-falsafì), der associeres med græsk gnosticisme og kristen neo-platonisme, og mystisk sufisme (al-tasawwuf al-dakhīl/al-tasawwuf al-tasawwufî), der associeres med en udefrakommende form for sufisme (Christman 2008).

Traditionel islam er således en nutidig ideologisk samlebetegnelse for en form for islam, der ser sig selv som en direkte fortsættelse af islams dominerende før-moderne paradigme, der strukturelt centrerer sig om vidensniveauerne islâm, imân og ihsân. Denne tredeling af islamisk viden bygger på den for islamisk teologi og religiøsitet centrale hadîth Djibrîl, der bl.a. gengives i Imam alNawawîs klassiske fyrre hadîth (al-Nawawî 1977). Ifølge denne hadîth udspørger englen Gabriel profeten om betydningen af begreberne islâm, imân og ihsân. Gennem hans svar indstiftes denne tredeling som en guddommeligt åbenbaret inddeling. Den traditionelle fortolkning er, at islâm omfatter korrekt praksis. Imân refererer til korrekt dogmatik og tro, mens ihsân omhandler islamisk spiritualitet/åndelighed. Som sådan positionerer neo-traditionel islam sig som en modpol til islamisme, salafisme, wahhabisme, reformisme og modernisme. Ifølge det neo-traditionelle islamiske paradigme er de fire store sunnitiske praksisdefinerende retninger (madhhab, pl. madhâhib) enestående repræsentanter for korrekt islamisk praksis (islâm). Ash'arî og Mâturîdîskolerne for islamisk teologi ( 'aqîlda), og i mindre grad visse grene af Hanbalî-skolen, accepteres som unikke repræsentanter for ortodoks islamisk tro og dogmatik (imân). De ortodokse islamiske sufi-ordner (turuq), især traditionen efter al-Junayd (d. 910), al-Ghazâlî (d. 1111) og de store tarîqastiftere, anses som autentiske repræsentanter for islamisk spiritualitet eller selvudvikling (ihsân) (Mathiesen 2009). 
Islamisk neo-traditionalisme er ikke blot en konservativ og konform gentagelse af tidligere generationers dyder og opfattelser. Som bl.a. Talal Asad har påpeget, er islamisk tradition diskursiv og bruges dynamisk og progressivt (som dette tilfælde viser) til at genopfinde og tilpasse islam i nye manifestationer og former til nye kontekster og tider (Hajj 2009). En af de få undersøgelser af den nutidige bâ'alawiyya-opblomstring i Tarîm, og i øvrigt af den neo-traditionelle strømning generelt, peger på at den skulle være selektiv i forhold til fortidens yemenitiske sufisme manifestationer. Bl.a skulle den diskursivt nedtone elementer som ekstatisk opførsel og mirakel narrativer, samt den mere spekulative Ibn 'Arabî inspirerede mysticisme, antageligvis fordi disse elementer er kontroversielle i en nutidig religiøs kontekst domineret af salafisme og modernisme (Knysh 2001). Knysh anfører dette som en hypotese, han opfordrer til at undersøge yderligere. Mit eget feltarbejde i Tarim samt mine studier af bâ'alawiyya traditionens klassiske værker modsiger delvist dette. Traditionens klassiske litteratur, f.eks al-Haddâds værker, falder ind under den 'ædru' (sahwî) sufisme, der generelt ikke beskæftiger sig meget med hverken ekstase eller mystisk kosmologi, omend en del med mirakler (karâmât). Desuden oplevede jeg ikke, at disse elementer blev nedtonet, når de forekom i de nutidige studiecirkler omkring klassiske værker, jeg deltog i under mit feltarbejde. De klassiske værker, inklusive deres kosmologi, læses snarere som indiskutable elementer i en kanon, der kognitivt knytter an til selve åbenbaringen. Også i de vestlige neo-traditionelle kontekster, jeg har studeret, er mirakelnarrativer almindeligt forekommende og accepterede. I nogen tilfælde (langt fra altid) refereres de med en snert af ironisk selvdistance, der måske i nogen grad afspejler den almindelige afvisning af mirakler, som dominerer det omgivende samfund. Amira Kotb har mere overbevisende peget på, at bâ'alawiyya-ordnen i nutiden udgør et kerneelement $i$ en social bevægelse og et transnationalt netværk (reseau transnationale), der sprænger grænserne for de traditionelle turuq i et fælles ideologisk opgør (agir ensemble) mod sekulære og statslige undervisningssystemer og former, der hævdes at underminere islam og fjerne muslimerne fra islam. Med den islamiske tradition som et magtfuldt ideologisk redskab peger man på disses manglende legitimitet. De repræsenterer, lyder kritikken, et brud på traditionens normer og praksisser for overlevering (tasalsul, idjâza, isnâd) og læring. Kotb peger ligeledes på bevægelsens meget høje grad af mobilitet og på at de i forvejen eksisterende transnationale netværk og strukturer, som kendetegner bl.a. bâ'alawiyya-ordnen, er en hovedårsag til, at denne nutidige bevægelse har kunnet brede sig så hurtigt. Det på trods af at den ikke er politisk organiseret og på trods af at den ikke blot ligger uden for rammerne af statslige og mellemstatslige institutioner, men endda på visse områder er i opposition til disse (Kotb 2004). Opgøret med bestemte 
undervisningsformer er centralt for denne bevægelse. Samtidig mener jeg dog at selve legitimeringen af bestemte former og modaliteter for islamisk praksis, identitet og selvbearbejdelse, ofte traditionelt forbundet med sufi-traditionen, inden for rammerne af normativ islam, er endnu mere centralt for den neo-traditionelle strømning (Mathiesen 2009).

Bâ'alawiyya-ordnen er idag et decentraliseret, multikulturelt, transnationalt fællesskab af murîd'er og tilhængere på mange forskellige niveauer, efterkommere såvel som ikke-efterkommere, der har slået rødder på alle seks kontinenter og bindes sammen af grader af orientering imod og tilknytning til de profetiske efterkommere og/eller den Tarîm-centrede geografi. Mit projekt er særligt knyttet til den gren af ordnen, der knytter sig til en nulevende ledende shaykh, al-Habîb 'Umar bin Hafîz (f. 1963), som er 39. generations efterkommer af Profeten. Denne grens fysiske centrum er universitetet Dâr al-Mustafâ i Tarîm, som er moderinstitution for et netværk af godt fyrre direkte relaterede læringsinstitutioner i Yemen og et vidt forgrenet netværk af relativt autonome relaterede moskeer, læringsinstitutioner, velgørenhedsprojekter, studiekredse, suficentre, medieplatforme, produktionsselskaber og på anden vis aktivistiske initiativer i Afrika, Asien, Australien, Europa og USA Disse er typisk grundlagt af tidligere elever fra Dâr al-Mustafâ ${ }^{2}$.

Jeg havde under mit feltarbejde i Tarîm i sommeren og efteråret 2011 mulighed for igennem observation og deltagelse at studere det didaktiske miljø og de læringspraksisser, som kendetegner Dâr al-Mustafâ og som danner forbillede for læringen i de relaterede institutioner og læringsnetværk. Det er i denne sammenhæng ikke muligt at redegøre beskrivende for den meget intensiverede sufi-relaterede islamiske praksis i Tarîm (Kotb 2004), men denne kontekst og interview med studerende, der har været igennem Tarîm eller stadig er der, er et centralt element $\mathrm{i}$ det grundlag for sammenligning med den internetbaserede læring som følger.

\section{Sunnipath/Qibla - where the night reaches}

Online universitetet Sunnipath, som blev grundlagt i 2003, er idag, efter eget udsagn, verdens største islamiske online læringsanstalt med mere end 1000 studerende med 80 forskellige nationale baggrunde pr. semester, avanceret brug af den nyeste e-lærings teknologi og veludviklede og professionelle undervisningsmoduler og studieprogrammer. Sunnipath, som fra Ramadan 2010 blev omdøbt til Qibla: for the Islamic Sciences ${ }^{3}$, startede som en Q \& A-tjeneste på nettet i kølvandet på katastrofen den 11. September, 2001. Folkene bag ideen var islamiske lærde og studerende, der alle

(C) Forfatteren og Tidsskrift for Islamforskning, ISSN 1901-9580, publiceret 27-4-2012 
var bundet sammen af et forhold til shâdhilî-miljøet i Hayy al-Kharabsheh i Amman, Jordan. Området er, udover at være hjemsted for et shâdhilî-zâwiya (suficenter), online-universitetet Sunnipath og en række andre læringsinstitutioner, desuden hjemsted for flere virksomheders distribution, produktion og forretning med forskellige islamiske produkter såsom bøger, tøj, parfume og bedekæder. Ligesom universitetet i Tarîm udgør dette praksisfællesskab et kernecenter for neo-traditionel islamisk læring og for paradigmets transmission til resten af verden. Mit feltarbejde i området i foråret 2007 og interviews med studerende, der har været igennem området, udgør et andet centralt sammenligningsgrundlag for undersøgelsen af den sufi-relaterede e-læring. Ideen, som hurtigt udviklede sig til også at inkludere online undervisning, var at skabe en mulighed for muslimer i ikke-muslimske lande for ved hjælp af moderne hjælpemidler at modtage autentisk og kvalificeret islamisk undervisning og indgå i læringsfællesskaber uden nødvendigvis at skulle rejse til den islamiske verden. Opfattelsen blandt stifterne var, at især muslimer i Vesten led under at moskemiljøernes undervisning ofte var uorganiseret, ukvalificeret og langt fra levede op til den islamiske læringstraditions standarder og sommetider var i direkte modstrid med denne. Underviserne på Sunnipath/Qibla er således alle kendetegnede ved at have modtaget idjâza ${ }^{4}$ i de discipliner og værker de underviser i, som oftest fra traditionelle lærde eller institutioner i Syrien, Yemen, Jordan eller Indien/Pakistan. Sunnipath fremstår idag som en international hovedeksponent for neo-traditionel islam, ikke mindst i Vesten og den engelsktalende verden.

Skiftet fra Sunnipath til Qibla markerer, udover navneskiftet og en videreudvikling af det didaktiske paradigme, også etableringen af et fysisk og sam-koordineret institut, Qibla, ved siden af onlineuniversitetet, således at studerende nu kan kombinere online-studierne med længere eller kortere studierejser og ophold i Jordan, bl.a. under de årlige Summer Intensives. Sloganet learn, change, inspire, opsummerer Qiblas vision; målet er at udklække eller kultivere mennesker, der kan inspirere andre åndeligt og religiøst på samme måde som Profeten, ledsagerne og de store awliyâ ' (helgener) gjorde og gør det. For at denne forandring kan foregå, må man først lære, hvordan man underkaster sig Allah i kærlighed og overgiver sin vilje til Ham. Det er selve denne underkastelse til Gud, der ifølge Qibla afstedkommer den moralske og spirituelle forandring, der er forudsætningen for at man senere kan inspirere andre ${ }^{5}$.

Neo-traditionel islam i nutiden er bl.a. kendetegnet ved et tæt organisatorisk samarbejde mellem forskellige toneangivende ordner og shuyûkh, herunder bâ'alawiyya-ordnen og shâdhiliyya-

(C) Forfatteren og Tidsskrift for Islamforskning, ISSN 1901-9580, publiceret 27-4-2012 
darqâwiyya-hâshimiyya ordnen i Hayy al-Kharabsheh, i Amman, Jordan. Begge grupper repræsenterer det samme grundlæggende neo-traditionalistiske islamiske paradigme og en række af underviserne, samt en del af undervisningsmaterialet på Sunnipath, har således tætte forbindelser til eller rødder i bâ'alawiyya-traditionen. Udveksling af studerende, fælles arrangementer og gensidige besøg er ligeledes meget udbredt. Det gælder bl.a. for kurset The Book of Assistance, der er en læsning af Imam ‘Abdallah bin 'Alawî al-Haddâds (d. 1720) værk ved samme navn (al-Haddad 1989), og kursets underviser, amerikaneren Abdulkarim Yahya, der er uddannet og mudjâz (en person der har idjâza) fra Tarîm, hvor han har boet og modtaget spirituel vejledning samt studeret de islamiske videnskaber hos en række anerkendte lærde igennem 12 år i miljøet omkring al-Habîb 'Umar bin Hafîz og det islamiske universitet Dâr al-Mustafâ. Netop dette kursus fungerer i det nedenstående som et repræsentativt eksempel på den type sufi-relaterede læringsfællesskaber og læring, der foregår ikke blot på Sunnipath/Qibla, men på et hastigt voksende marked for internetbaseret islamisk undervisning.

Som en del af mit PhD-feltarbejde har jeg i løbet af 2010-11 fulgt fem forskellige kurser på Sunnipath og en række andre internetbaserede neo-traditionelle læringsportaler. Kurset er ikke tilsigtet en snæver eller afgrænset sekterisk bâ'alawiyya kontekst. Selvom både kursets eneste grundbog og dets underviser specifikt er eksponenter for Tarîm traditionen, er deltagelse generel og ved betaling åben for alle, uanset om de har taget bay' $a^{6}$ hos en bâ'alawiyya shaykh eller ej. Bay'a anses ofte for at være et konstituerende element ved sufismen idet det repræsenterer den tætte relation mellem murîden og shaykhen på den ene side og murîden og en bestemt tarîqa på den anden (Schimmel 1975) I bâ'alawiyya-traditionen er bay'a i modsætning hertil ualmindeligt og tilhørsforholdet løsere funderet. Langt de fleste studerende på Dâr al-Mustafâ og stort set alle i den bredere kreds af folk, der besøger eller kommer til stedet jævnligt, har således ikke taget officiel bay'a hos shaykhen selvom de ofte følger ham og hans undervisning igennem mange år ${ }^{7}$. Denne strukturelle åbenhed og fraværet af ekskluderende sekterisk praksis og sprogbrug udtrykker en egenskab ved bâ'alawiyya-ordnen, der historisk set adskiller den fra flere andre traditionelle sufiordner og som samtidig er et grundtræk ved den brede mainstream af den neo-traditionalistiske sufisme-orienterede strømning (Stjernholm 2011). Vidt forskellige niveauer af deltagelse accepteres. Selv i den inderste kreds af de mest dedikerede murîds (khâss al-khâss), defineres fællesskabet som bredt funderet, omend referencer til bâ'alawiyya ordnens hovedskikkelser, dens litteratur og metode, den særlige sakrale geografi der knytter sig til Tarîm og Hadramawt (Ho 2006)

(C) Forfatteren og Tidsskrift for Islamforskning, ISSN 1901-9580, publiceret 27-4-2012 
samt det centrale fokus på tilhørsforholdet til og helligholdelsen af Profetens familie selvsagt alle er dominerende faktorer. På samme måde er alle de praktiske anvisninger og definitioner, der gives i The Book of Assistance, funderet i et bredere og mere generelt accepteret sunnitisk-sufisk paradigme, der har rødder i traditionen fra al-Junayd og al-Ghazâlî og altså tiden inden opkomsten af de institutionaliserede sufi-broderskaber.

\section{The wings of the angels surround halaqas}

Første undervisningsgang af ti gange to timer går med at grundlægge fornemmelsen af fællesskab inden for rammerne af det virtuelle klasseværelse, at introducere emnet og den specifikke e-lærings teknologi, samt at etablere en fælles intention (niyya) med kurset. Formuleringen og kultiveringen af oprigtigt fromme og gudfrygtige intentioner for sine handlinger er central i islamisk lov og åndsliv (al-Nawawî 1977; Powers 2004). Den første hadîth i Imam al-Nawawîs samling af de 42 mest paradigmatiske profetiske overleveringer gør gældende, at alle handlingers værdi i forhold til Gud ligger i den intention, der er deres grundlag, innamâ al- 'imâl bil-niyyât (al-Nawawi 1977). Netop denne hadith indleder som regel alle islamiske undervisningscirkler og således også denne og gentages løbende gennem kurset. Der har allerede, et par dage forinden, været en generel introduktion til semesteret, som er fælles for alle studerende. Ligeledes har underviserens assistent over mailen opfordret folk til at præsentere sig selv for de andre, og der har været en del relaterede udvekslinger. Folk præsenterer, hvor de kommer fra, og underviseren noterer de forskellige byer og lande ind på det store verdenskort, der er lagt ud som slide på den fælles tavle, som alle har oppe på deres egen skærm. "Where are you? Tell us something good about your community," skriver underviseren på tavlen og forklarer samtidig, hvorledes der i e-klasseværelset er en tavle og en præsentation med slides, som man kan klikke sig ind på. Han beder nogle om at svare pr. tekst på chatten, som kører parallelt med tavlen i højre side af skærmen, mens han vil have andre til at svare ved hjælp af den mikrofon som kan sendes rundt til de tilstedeværende i lokalet; "please raise your hands if you're interested in talking about your community on the mic." Ved siden af ikonet med mikrofonen til venstre på skærmen, som man skal klikke på, når man får mikrofonen tildelt, er ikonet med hånden, der betyder, at man rækker hånden op. Man kan, i modsætning til andre kurser på Sunnipath/Qibla, ikke se Yahya, men kun høre hans stemme. Dette kursus er udelukkende bygget på live sessioner, i modsætning til andre kurser, der kombinerer live sessioner med optagelser, der er foretaget på forhånd. De enkelte undervisningselementers materiale er 
tilgængeligt som optagede filer, slides og eventuelle personlige noter, på elevernes private Ecampus site i op til et år efter undervisningsforløbets afslutning.

De studerende er fra hele verden og hver især præsenterer sig selv. Byer i Mauritius, Tyrkiet, Australien, England, USA, Canada, Danmark, Malaysia, Singapore, Indien markeres ind på kortet, og vi bliver introduceret til vidt forskellige lokale muslimske samfund og fællesskaber (communities). En australsk søster (alle tituleres brødre og søstre i klasseværelset) fra Perth, med tyrkiske aner, beskriver, hvorledes hun lever isoleret langt væk fra andre muslimer og langt fra den nærmeste moske. En gruppe fra Wellington i New Zealand, hvor der i alt er ca. 3000 muslimer, har stiftet en lokal studiegruppe, indenfor rammerne af hvilken de skal mødes for at studere kursets undervisning sammen. Fra Luton i London-området forklarer en mand, at det lokale muslimske samfund er meget aktivt, multikulturelt og blomstrende, og at man nemt finder moskeer, islamisk undervisning, dhikr-grupper og halal-produkter. Fra Jacksonville, Florida fortæller en mand med egyptiske rødder om et stort muslimsk samfund med mere end tusind deltagere til de lokale fredagsbønner. Andre fortæller om meget små og unge lokale muslimske samfund med ned til 1012 personer i landsbyområder af USA og England, mens andre kommer fra samfund med århundreders muslimsk tilstedeværelse og historie. De studerende er en blanding af kvinder og mænd, nye muslimer og folk med muslimske rødder, folk fra vestlige samfund med immigrantbaggrund og folk fra traditionelle muslimske samfund, unge enlige og familiefædre og mødre, studerende og folk med fast arbejde. Med henvisning til en profetisk hadith udbryder Yahya forundret, da han har opridset konturerne for et klasseværelse, der strækker sig fra New Zealand til den amerikanske vestkyst; "The wings of the angels surround halaqas - so it's pretty amazing if angels surround this halaqa. InshaAllah, the baraka of that will envelop all those in between." Et par minutter senere reflekterer han igen over hvorledes dette klasseværelse afspejler profetens sandfærdighed, idet denne ifølge en hadith skulle have sagt; liyablughanna hadhâ al-amr mâ balagha al-layla wa al-nahâr - "Let this affair reach wherever the night and day reaches". "Where the night reaches", står med store bogstaver hen over landkortet på skærmen. Referencen til elæringsfællesskabets fysiske geografiske fundament og italesættelsen af relationen til specifikke lokale fællesskaber udspringer imidlertid af mere end blot en fascination af dette. Kursusdeltagerne forbindes gennem internet-kurset via kursusbogen og underviseren, der legemliggør bâ'alawiyyatraditionen, Shaykhen og Tarîm, til den traditionelle islamiske arv som søges transmitteret. Kursusdeltagerne bliver på den anden side også selv gjort ansvarlige for at bringe det de lærer 
videre ud i deres egne lokale fællesskaber. Det enorme fokus på da 'wa (kaldet til islam) der i bemærkelsesværdig grad kendetegner Dâr al-Mustafâ og Tarîm-traditionen (al-Haddad 1989; Ho 2006; Knysh 2001) og som pålægges de studerende som et centralt kollektivt og personligt religiøst ansvar, er ligeledes centralt i e-praksisfælleskabet, og internettet bliver derfor et vigtigt middel til traditionens transmission.

Undervisningen følger en afart af et velkendt mønster, der kendetegner islamiske læringsmiljøer på tværs af historien. Eleverne læser en tekst op for læreren og de øvrige elever, mens læreren løbende afbryder oplæsningen for at kommentere og uddybe tekstens indhold og betydning. Man kan stille spørgsmål over chatten, som bliver besvaret undervejs, eller når et kapitel afsluttes, hvilket er en parallel til den klassiske læringssituations almindelige metode, hvor eleven typisk skriver spørgsmålet ned på et stykke papir og sender det op til læreren eller indikerer, at han har et spørgsmål.

\section{The Book of Assistance}

Kurset The Book of Assistance har det samme erklærede mål som andre sufisme-orienterede praksisfællesskaber, nemlig personlig udvikling/forandring, her forstået eller defineret som en større nærhed på eller intimitet med Gud (qurb min Allah) og tilstedeværelse (presence) med Allah. Al-Haddads værk, som er kursets tekstbog, kan betegnes som en spirituel selvhjælps-manual fra det 17. århundrede og hensigten med bogen er ifølge forfatteren selv, som skrev den som en brevkorrespondance med en murîd, at bibringe en konkret og let tilgængelig individuel handlingsvejledning. En skandinavisk bâ'alawiyya-informant med mere end ti år på tarîqaen og flere års studier på Dâr al-Mustafâ i Tarîm forklarede mig med henvisning til sin shaykh, at en alternativ måde at få en spirituel åbning (fath) på, er ved permanent at implementere netop denne bogs anvisninger i sit liv. Han grinede indforstået og resignerende da han forklarede mig dette velvidende at det program, bogen foreskriver, er stort set umuligt at implementere til fulde, i det mindste når man er alene og lever i Vesten. Igennem de 32 kapitler præsenteres det guddommeligt sanktionerede praksis- og eksistensmodus, dvs. det profetiske ${ }^{8}$, der i stigende grad skal gennemsyre alle aspekter og øjeblikke af murîdens liv, og som på samme tid legemliggør og afstedkommer tilnærmelsen til Gud og opnåelsen af den mystiske eksperimentelle indsigt eller det værensmodus ( $m a$ 'rifa billah), som traditionen sigter imod. Der præsenteres metoder til at kultivere den korrekte moral, det korrekte sindelag, emotioner og brug af intellektet. Ydermere den sande 'aqîda og 
længsel efter, kærlighed til og frygt for Gud og hvordan man overvinder sit nafs ${ }^{9}$ (ego) og undgår at fortabe sig i Satans falske løfter og tilhviskelser og dunyâs allestedsnærværende bedrag (al-Haddad 1989). Følgende eksempel fra kapitlet om socialt ansvar belyser hvorledes den, der søger Gud overordnet set skal kultivere og forholde sig til 'sin personlige flok' (ra 'iyyatuka al-khâssa); tunge, ører, øjne, mave, genitaler, hænder og fødder.

These are your charges which God has given you and a trust with which He has entrusted you, which you should restrain from sin and use in His obediance. For God the Exalted created them only that by means of them you might obey Him; they are among the greatest of His favours, for which we should thank Him by using them to obey Him and not in His disobediance. If you do not do this you will be turning God's favour into ingratitude (alHaddad 1989: 86).

For at indse, hvad dette ansvar indebærer, kræves et indgående kendskab til Guds ordrer og åbenbaring ( 'ilm), studiet af shari'a i bredeste forstand forstået som summen af den islamiske lære og i særdeleshed fiqh. Fokus for den neo-traditionelle islamiske selvbearbejdning kan ikke isoleres til blot at være en abstrakt menneskelig subjektivitet, bevidsthed eller ånd. Tværtimod sigter murîden mod en mere omfattende transformation af hele den menneskelige entitet inklusive dens fysiske manifestation, diskursive praksis og socialitet, dens emotionalitet, perception, kognition og konation, samt dens moral og generelle praksis i og omgang med verden, igennem en fuldstændig underkastelse til Guds åbenbarede vilje. Begrebet eller fænomenet tahqîq al- 'ubûdiyya, at blive Guds fuldkomne tjener, beskriver denne aspiration. Den konstante stræben efter denne tjenstvillighed, hengivenhed og gudsbevidsthed i alle øjeblikke er murîdens vej eller metode, hans tarîqa, og den eneste måde hvorpå han kan overvinde nafset. Gud skænker sin eksperimentelle mystiske indsigt ( $m a$ 'rifa billah) og afslører sig og sine hemmeligheder for den hengivne, søgende tjener (al-Haddad 1989). Netop fordi bogen er en selvhjælps-manual, er den måske særligt velegnet til e-læringens distancerede og ikke-fysiske interpersonelle relationer. Selve de praksisser, der introduceres, samt bogens formuleringer, præcise gengivelser af forbønner $\left(d u^{\prime} a\right)$, brug af didaktiske narrativer og dens måde at referere til koranen, Profeten og sufismens hovedskikkelser afspejler alle dens oprindelige intention og er i sig selv kursets bærende motiverende faktor. 
Den intention for kursusdeltagelsen, som formuleres som det allerførste og sidenhen gentages ofte igennem de 10 undervisningsgange, gør bl.a. gældende at den studerende deltager for at lære om og efterfølgende praktisere og videregive den korrekte koraniske og profetiske handlemåde for derigennem at søge Allah's countenance, nearness, pleasure and reward. Løbende opfordres de studerende til at praktisere det, de lærer, og den korrekte måde at læse bogen på er ifølge Yahya at man først tager hul på et nyt kapitel når man har påbegyndt den praktiske applicering af det kapitel, man just har afsluttet.

\section{Tilstedeværelse i e-praksisfallesskabet og LPD}

Yahya indbyder den første elev til at tage imod mikrofonen og begynde oplæsningen, men det viser sig, at denne sidder i en aftentidszone og sidder med hovedtelefoner på i et rum med slukket lys og tilser sine børn, mens de er ved at falde i søvn. Dette belyser et centralt aspekt ved elæringssituationen, som gør den væsensforskellig fra den klassiske halaqa-undervisning. Elevernes og lærerens tilstedeværelse i klasseværelset er begrænset til et bevidsthedselement, samt en stemme, hvis de bidrager til oplæsning eller kommentering, og ord skrevet på taster i chatten. Den komplekse udveksling af ikke-verbaliseret kommunikation, emotioner, stemninger og legemlig tilstedeværelse og deltagelse, der kendetegner den situerede læring igennem fysisk-konstitueret LPD, er således afgørende begrænset. Det indebærer, at adgangen til og gennemsigtigheden af praksisfællesskabets teknologier primært etableres gennem den didaktiske diskursproduktion. Dynamikken i et virtuelt klasseværelse er derfor væsensforskellig fra den traditionelle læringstradition, som Qibla i øvrigt profilerer sig på at ligge i forlængelse af. Islamisk sufisme er som nævnt ovenfor kendetegnet ved at have et dybtgående og omfattende selv-transformerende sigte. Det langvarige samvær med shaykhen og de øvrige murîder, suhba, er centralt for disse forandringers udfoldelse og den gensidige spejling og idealisering, for at bruge begreber fra et objektrelationsteoretisk læringsunivers (Hermansen 2001), er vigtig for tilegnelsen af selvtransformationens teknologier (Schimmel 1975; Pinto 2010). Begrebet suhba har den samme rod på arabisk (ص-حب) som sahâba, betegnelsen for de profetiske ledsagere. Netop de indbyrdes relationer mellem Profeten og ledsagerne udgør den grundmodel på hvilken forholdet mellem shaykh og murîd bygger. Suhba, som den manifesterer sig i begge de to ovennævnte fysiske praksisfællesskaber, indbefatter interpersonel læring gennem stærkt intensiverede sunna-baserede former for praksis, ritualudførelse og diskursbrug og at specifikke sociale og personlige attituder, opfattelser og måder at opføre sig på efterstræbes opretholdt. Ovennævnte skandinaviske informant 
beskriver det "som at være i selskab med Profeten. Shaykhen sætter et spejl op foran dig så du klart og tydeligt kan se dit nafs og alle dine fejl og mangler. Det er en meget smertefuld proces ${ }^{10}$." En britisk murîd som jeg snakkede med i Tarîm, og som havde studeret flere år i landet beskrev sin egen erfaring med tarîqaens selvbearbejdningsprojekt og kontekstens betydning; "The nafs is like a piece of dirty cloth. Back home you try to cleanse it but because the water you use is dirty the cloth remains dirty. In Tarîm the water is clean and the cloth is cleansed just by your putting it into it ${ }^{11}$." Sidstnævnte indebærer ikke, at selvbearbejdelsen i Tarîm opleves som nem, men indikerer blot at konteksten opleves som havende afgørende betydning for den. Situeret læring gennem LPD i praksisfællesskabet synes altså at være en vigtig pointe ved den traditionelle suhba. Den kollektive aspiration efter spirituel renselse afstedkommer en motivationssynergi og en praktisk socialisering og en kognitiv og emotionel opøvelse i den livsverden og de særligt velansete rituelle og moralske handlemønstre, som den islamiske tradition foreskriver, og igennem hvilke tilnærmelsen til Gud sker.

I e-praksisfællesskabet er der en afgørende opsplitning i forhold til den traditionelle suhbas LPD. Læringsfællesskabet er adskilt fra et praksisfællesskab, hvor læringen kan udfolde sig igennem individets gradvise interaktion med den praksis i shaykhens nærhed, der anses for at være en legemliggørelse af åbenbaringen og traditionens idealer. En meget høj grad af isolation fra omverdenen kendetegner praksisfællesskaberne i både Yemen og Jordan. De enkelte onlinekursisters særegne sociale livsverden, med det væld af variation som er præsenteret ovenfor, er alt andet lige kendetegnet ved ikke at dele murîdens sufiske aspiration og ordnens centrale islamiske livsverdenselementer, der defineres og etableres kollektivt i det traditionelle og isolerede suhbapraksisfælleskab. På trods heraf er det i denne kontekst kursusbogens praksis og den spirituelle forandring skal manifestere sig. E-læringen er på den måde individualiseret, idet den studerende er alene om at forsøge at implementere og afstedkomme den altomfattende og svære kropsliggjorte spirituelle forandring som kurset tilsigter.

\section{Motivation i e-læringsfællesskabet}

I e-klasseværelsets chat rejser de studerende deres spørgsmål og kommer med kommentarer. I løbet af de ti kursusgange bliver der på intet tidspunkt sat spørgsmålstegn ved det paradigme eller definitionen af de basale elementer i den livsverden, kursusbogen og læreren repræsenterer. Kurset henvender sig altså til folk, der allerede på forhånd har et indgående kendskab til, tro på og accept

(C) Forfatteren og Tidsskrift for Islamforskning, ISSN 1901-9580, publiceret 27-4-2012 
af, og lever inden for rammerne af, denne traditionelle islamiske livsverden. De grundlæggende kognitive og trosmæssige elementer og logikker af denne kosmologi er således etableret i den enkelte. Samtidig er det klart, at selvom de specifikke islamiske livsverdenelementer måske ikke indstiftes eller introduceres i e-læringsrummet, bliver de ikke desto mindre bekræftet og indøvet således, at de yderligere stadfæstes. Dette understreger i øvrigt den tætte forbindelse til andre kurser i de forskellige fler-årige kursusprogrammer, der ikke er specifikt sufisme-orienterede. EPraksisfællesskabet bliver dermed en diskursiv opøvelse af en bestemt verdensopfattelse, som i sig selv er en central ramme for at selvets teknologier kan komme i spil. Motiveringen af den enkelte til at stræbe yderligere efter spirituel renselse og en mere gudshengiven livsførelse sker således grundlæggende gennem en aktivering af denne livsverdens bestanddele og gennem den eksistentielle mening, den troende i forvejen oplever i eller tillægger sin verden. I sin bog om islamiske kassettebåndsprædikener afdækker Charles Hirschkind aspekter ved den etiske lytning til moralske læringsnarrativer og religiøs vejledning. Da lytningen foregår inden for rammerne af en islamisk livsverden peger Hirschkind dels på at den aktiverer på forhånd kultiverede psykosomatiske og emotionelle dispositioner i det lyttende individ, og dels på at lytningen er med til at kultivere disse sensoriske dispositioner (Hirschkind 2006: 80ff). Onlinelæringen kan med visse forbehold forstås som en slags interaktiv og mere avanceret version af Charles Hirschkinds kassettebåndsprædikener, og mange af de samme motivations- og demotivationsdynamikker går givetvis igen i denne kontekst (Hirschkind 2006: 80ff) ${ }^{12}$. Ofte er det centrale således ikke at lære noget nyt, men at blive mindet om noget man i forvejen godt vidste på en ny måde for der igennem at blive inspireret.

En informant og onlinekursist, som har delt sin erfaring af onlinelæringen med mig, påpeger at det at lytte til kurserne kan afstedkomme en kraftig motivation for forandring og etablering af nye praksisser i ens liv, men at denne motivation ofte daler med tiden, og at man "glemmer hvad man har lært", ${ }^{\prime 13}$ En del af forklaringen på dette fænomen kan måske findes i selve karakteren af de medier, der er tale om og selve manglen på et fysisk konstitueret læringsmiljø. Flere informanter fra Tarîm pegede netop på at tilstedeværelsen af 'et omkringliggende miljø der fuldstændig understøtter den spirituelle vej og griber dig (ilî yamsakak - citatet er fra en samtale med en syrisk informant) når du falder fra' er vigtigt for at man kan opretholde den meget intensiverede religiøse praksis på lang sigt. En vis skepsis i forhold til om disse medier er velegnede til den type dybere selvforandring, der tilsigtes, er derfor velbegrundet Mine undersøgelser af læringsoplevelser i

(C) Forfatteren og Tidsskrift for Islamforskning, ISSN 1901-9580, publiceret 27-4-2012 
forhold til den neo-traditionelle selvbearbejdning peger imidlertid på, at lignende motivations/demotivationskurver også kendetegner traditionelle og fysisk konstituerede læringskontekster som moskeer og i øvrigt også de kernepraksisfællesskaber i Yemen og Jordan, som er nævnt ovenfor. Stort set alle de informanter, jeg har arbejdet med i studiet af det neo-traditionelle selvudviklingsparadigme, har givet udtryk for store frustrationer forbundet med at gennemgå de personlige forandringsprocesser, som traditionen foreskriver. Det gælder også dem, der i mange år har indgået $\mathrm{i}$ isolerede praksisfællesskaber, der kollektivt søger mod det. At tage kampen op mod sit nafs er en omkostningsfuld og krævende affære og noget som opfattes som et personligt livsprojekt der i vigtighed rangerer højere end alle andre ambitioner og personlige projekter i de fleste af mine informanters liv, i det mindste i deres selvitalesættelse. Oplevelsen af egen syndighed og skam over ikke at kunne leve op til det præsenterede ideal bliver derved en central motivationsfaktor. Selve optegnelsen af idealets konturer er den individualiserede e-lærings centrale akse og bogens sigte. Da e-læringen samtidig er kendetegnet ved ikke at være situeret inden for rammerne af et praksisfællesskab, hvor forekomsten af synd og skam og måder at forholde sig til disse på er en del af læringen gennem LPD, er det sandsynligt, at skammen har endnu mere motivations/demotivationspotentiale i denne kontekst. Yahyas konstante påmindelse om at være varsom med at forsøge at antage for store ambitioner, og pålægge sig selv mere omfattende praksisser, end man er i stand til vedholdende at opretholde, går igen som et mantra gennem kurset. Det afspejler bevidstheden om skammens på en gang motiverende og demotiverende potentiale.

Selvbearbejdningen er en langstrakt proces, der varer livet igennem. Hellere antage få praksisser, der varer ved og potentielt kan forøges gradvist, end at pålægge sig selv en masse i gejsten over at have visualiseret idealet, for på sigt at miste det hele igen ${ }^{14}$.

Midtvejseksamenen og den afsluttende eksamen er kendetegnet ved, at den studerende skal give eksempler på konkrete praksisser fra hver undervisningsgang, som kan appliceres i ens eget liv. Denne tilkendegivelse på skrift bliver en slags selvovervågningsteknik (murâqaba) og berører det store etiske ansvar over for egen implementering af den teoretiske lære, som den studerende står over for. Netop i denne situation foretager den studerende en slags talehandling ind $\mathrm{i}$ onlinepraksisfællesskabets virkelighed, og selv om handlingen er distanceret og intellektualiseret, vil den studerende igennem denne handling blive klar over, om det, han eller hun giver udtryk for på tekst, afspejler den praktiske virkelighed eller ej. Det centrale islamiske etik-begreb riy $\hat{a}$ ', bevidst at iscenesætte sig selv eller opføre sig på en måde, der udtrykker en større grad af 
religiøsitet end hvad, der er sandt, for at opnå en højere status - en praksis, der står i opposition til det islamiske praksisideal - bliver dermed en motiverende faktor inden for rammerne af det ikkefysiske læringsfællesskab, selvom der ikke forekommer nogen reel fysisk handlingsudveksling.

Flere af mine informanter, som ikke har den eksklusive daglige adgang til fysisk suhba med de spirituelle mestre, fortæller at de bruger online-faciliteter til at skabe rum for samvær med deres shuyûkh. F.eks når oplevelsen af afsavn og adskillelse, grundet den fysiske adskillelse, synes for stort. Denne mulighed udgør en ikke uvæsentlig del af det personlige emotionelle religiøse liv, derved at den er med til at reaktivere og fremkalde emotioner, spirituelle oplevelser og minder fra faktiske fysiske møder, som murîden tidligere har haft med sin shaykh. På youtube, facebook og andetsteds på nettet distribueres og kopieres indslag ofte fremelsket af bâ'alawiyyerne selv. De tilskæres, omklippes og oversættes, samtidig med at de bliver diskuteret og kommenteret på af brugere. Som sådan skabes et bibliotek eller et forum af offentligt tilgængeligt og interaktivt materiale. Selve sunnipath-kurset er beskyttet under ophavsretslige love, og al distribution er forbudt. Ikke desto mindre kan et centralt motivationselement for den enkelte kursusdeltager være netop, at det medvirker til genkaldelse af minder som nævnt ovenfor og som derved bliver en del af læringsrummet. At Yahya er al-Habîb 'Umars personlige oversætter i Tarîm og sidder side om side med ham på flere af de internettransmitterede sessioner, som udsendes til resten af verden, og når denne er på rejser til resten af verden, gør, at de studerende vil associerere hans stemme med shaykhen selv og altså med møder, de har haft med ham. E-sufisme har derved bibragt en dimension til det religiøse liv, en mulighed for tilstedeværelse, der traditionelt set og parallelt hermed kan fremmanes gennem brug af mentale visualiseringer eller ting skrevet på skrift. Klippene bruges således aktivt $\mathrm{i}$ helt nye afarter af istihdâr (hidkaldelse af tilstedeværelse) for at bibringe og lade sig motivere af det profetiske lys, som de profetiske efterkommere efter sigende besidder.

\section{Opsummering}

Med udgangspunkt i en omtænkning af Foucaults begreb selvets teknologier (Foucault 1988) til en sunni-muslimsk kontekst har jeg i ovennævnte givet et bud på hvilken rolle e-læring spiller for tilegnelsen og transmissionen af metoder til islamisk selvbearbejdning. På basis af især Lave \& Wengers socialpsykologiske læringsteori (Lave og Wenger 1991) har jeg analyseret, hvorledes transnational, neo-traditionel sufisme-relateret e-læring adskiller sig fra læringen i mere

(C) Forfatteren og Tidsskrift for Islamforskning, ISSN 1901-9580, publiceret 27-4-2012 
traditionelle praksisfællesskaber relateret til særligt bâ'alawiyya-ordnen. Internet spiller en tiltagende stor rolle for læring og transmission af islam og neo-traditionelle islamiske selvbearbejdningsteknologier. Afskåret fra de traditionelle praksisfællesskabers kontekst og suhba er den omfattende selvbearbejdning i meget høj grad individualiseret. Den fysiske tilstedeværelse og læring gennem kropslig deltagelse i et isoleret praksisfællesskab, der er konstitueret ved intensiveret islamisk selvbearbejdning, findes ikke i e-læringen. For deltagere i elæringsfællesskaber etableres adgangen til læringen af selvets teknologier derfor, isoleret set, alene via den didaktiske diskursproduktion, og det foreslås derfor at læringsproduktet er markant anderledes fra traditionelle læringskontekster. Det er imidlertid vigtigt at e-læringen ofte netop er et supplement til deltagelse i andre typer af islamiske praksis- og læringsfælleskaber og i øvrigt til andre typer af transmission af det neo-traditionelle selvbearbejdningsparadigme. Læringen i elæringsfællesskabet motiveres via en diskursiv opøvelse, bekræftelse og uddybning af individets kognitive, kropslige og emotionelle relation til og tilstedeværelse i den traditionelle islamiske livsverden. Visualiseringen og tilegnelsen af et islamisk eksistens-/praksisideal er central. Netop fordi e-læringen er afskåret fra mere traditionelle former for LPD, inklusive de måder man inden for rammerne af traditionelle praksisfælleskaber forholder sig til den udbredte frustration og skam over ikke at leve op til det præsenterede ideal, foreslås det at den personlige oplevelse af skam, isoleret set, er en endnu kraftigere motivations-/demotivationsfaktor i e-læringen. Centrale elementer i den traditionelle selvbearbejdning, såsom murâqaba og riyâ', findes i e-læringen via særlige eksamensformer, hvor den enkelte tvinges til konkret at forholde sig til graden af egen praksisimplementering igennem en diskursiv handling ind i læringsfællesskabet. Endelig giver elæringen, igen ofte som supplement til mere fysisk konstituerede kontekster, mulighed for helt nye former for istihdâr, der spiller en stor rolle for den enkeltes gradvise selvbearbejdning og opøvelsen i og tilegnelsen af selvets islamiske teknologier.

\section{Referencer}

Al-Haddad, Imam Abdallah Ibn Alawi, 1989: The Book of Assistance (oversat fra arabisk (risâla al-mu'âwina wa al-muzâhira wa al-muwâzira lil-ghâribîn min al-mu'minîn fî̀ sulûk tarîq al-âkhira, af Mostafa al-Badawi), Dar al-Faqih, UAE.

Al-Nawawî, Abû Zakariyyâ Yahyâ, 1977: An-Nawawī's Forty Hadith (translated by Ezzeddin Ibrahim and Denys Johnson-Davies), The Holy Quran Publishing House, Damascus.

(C) Forfatteren og Tidsskrift for Islamforskning, ISSN 1901-9580, publiceret 27-4-2012 
Al-Qushayrî, 'Abd al-Karîm ibn Hawâzîn, 1990: Principles of Sufism/by al-Qushayri (translated from the Arabic by Von Schlegell, B.R.), Mizan Press, Berkeley, USA.

Al-Seyyid Sabîh, Dr. Muḥammad, 2007: hatâ lâ tậ̣̂' al-hawiyya al-sûfiyya, Dâr al-rukn wa almaqâm, Cairo, Egypt.

Anderson, Jon W., 2003: The internet and Islam's new interpreters, in: New media and the Muslim world: the emerging public sphere, Indiana University Press, USA.

Asad, Talal, 1986: The idea of an anthropology of Islam, Occasional Papers Series, Center for contemporary Arab studies, Georgetown University.

Asad, Talal, 1993: Genealogies of Religion: Discipline and Reasons of Power in Christianity and Islam, Johns Hopkins University Press, Baltimore, USA.

Bang, Anne K., 2000: Sufis and scholars of the Sea, Thesis for the Degree of Dr. Art, University of Bergen.

Bearman, P. Th. Bianquis, C.E. Bosworth og E. van Donzel, 2011 (red): Encyclopaedia of Islam, Second Edition, Brill Online.

Benzine, Rachid, 2004: Les nouveaux penseurs de l'islam, Albin Michel S.A, Frankrig.

Bourdieu, Pierre, 1977: Outline of a theory of practice, Cambridge University Press, Cambridge.

Bunt, Gary R., 2003: Islam in the digital age: e-jihad, online fatwas and cyber Islamic environments, Pluto Press, London.

Bunt, Gary R., 2009: iMuslims: rewiring the house of Islam, University of North Carolina Press, USA. 
Bujra, S. Abdalla, 1971: The Politics of Stratification, Oxford University Press, UK.

Christman, Andreas, 2008: 'Reclaiming mysticism', i Green, Nile (red.): Religion, Language and Power, Routledge, UK.

Foucault, Michel, 1988: 'Technologies of the self' i Martin, L.H. et al: Technologies of the Self: A Seminar with Michel Foucault, London, Tavistock, 6-49.

Freitag, Ulrike, 1999: 'Hadhramaut: A Religious Centre for the Indian Ocean in the Late 19th and Early 20 $20^{\text {th }}$ Centuries?', Studia Islamica, No. 89 (1999): 165-183.

Freitag, Ulrike og Clarence-Smith, William G., (red). 1997: Hadhrami traders, scholars and statesmen in the Indian Ocean, 1750s-1960s, Brill, Leiden.

Geaves, Ron, 2006: 'Learning the lesson from the neo-revivalist and Wahhabi movements', i Malik Jamal og Hinnells, John (red): Sufism in the West, Routledge, Oxon, UK.

Gianotti, Timothy J., 2011: 'Beyond Both Law and Theology: An Introduction to al-Ghazâlî's "Science of the Way of the Afterlife", i Reviving Religious Knowledge (Ihyā' 'Ulûm al-Dîn), The Muslim World, vol. 101, Blackwell Publishing, Oxford.

Haj, Samira, 2009: Reconfiguring Islamic Tradition, Stanford University Press, USA.

Hermansen, Mads, 2001: Laringens Univers, Forlaget Klim, Aarhus, DK.

Hirschkind, Charles, 2006: The Ethical Soundscape, Columbia University Press.

Ho, Engseng, 2006: The Graves of Tarim, University of California Press, USA.

Karamustafa, Ahmat, 2007: Sufism, the formative period, Edinburgh University Press, Edinburgh. 
Kotb, Amira, 2004: La Tarîqa Bâ'alawiyya et le développement d'un réseau soufi transnational Université Paul Cezanne Aix-Marseille III, unpublished.

Knysh, Alexander, 2001: 'The tariqa on a land cruiser', Middle East Journal, vol. 55, 3.

Knysh, Alexander, 2007: 'Contextualizing the Salafi - Sufi conflict (from the

Northern Caucasus to Hadramawt)', Middle Eastern Studies, 43:4, 503-530.

Lave, Jean og Wenger, Etienne (red) 1991: Situated Learning - Legitimate Peripheral

Participation, Cambridge University Press, UK.

Mathiesen, Kasper, 2009: Answering Salafism and Modernity, uudgivet Master's Thesis ved Københavns Universitet.

Mahmoud, Saba, 2005: Politics of piety: Islamic revival and the feminist subject, Princeton University Press, USA.

Pappé, Ilan, 2010: The Modern Middle East, Routledge, Oxon, UK.

Pinto, Paulo G., 2010: 'The Anthropologist and the Initiated: Reflections on the Ethnography of Mystical Experience among the Sufis of Aleppo, Syria', Social Compass 57: 464.

Powers, Paul R., 2004: 'Interiors, Intentions and the "spirituality" of Islamic ritual practice', Journal of the American Academy of Religion, Vol. 72(2): 425-4.

Schimmel, Annemarie, 1975: Mystical Dimensions of Islam, The University of North Carolina Press, USA, 1975.

Sirriyeh, Elizabeth, 1999: Sufis and anti-Sufis, RoutledgeCurzon, London.

Stjernholm, Simon, 2011: Lovers of Muhammad: A Study of Naqshbandi-Haqqani Sufis in the 
Twenty-First Century, dissertation for the degree of $\mathrm{PhD}$, Lund Studies in History of Religions,

Lund, 2011.

Wilcox, Andrew, 2011: 'The Dual Mystical Concepts of Fanâ' and Baqâ' in Early Sûfism', British Journal of Middle Eastern Studies, 38(1): 95-118.

\section{Om forfatteren}

Kasper Mathiesen er Bachelor i religionsvidenskab og Master i Islamiske Studier fra Københavns Universitet (2009). Siden 2010 har han været ansat på Aarhus Universitet, Institut for Kultur og Samfund, på et $\mathrm{PhD}$-projekt om neo-traditionel Islam, nutidig transnational spiritualitet og religiøs læring. Hovedfokus i forskningen er Ba'alawi-traditionen, en oprindeligt yemenitisk tradition, der i løbet af de sidste ca. 500 år er blevet spredt over hele regionen omkring det Indiske Ocean. I nutiden har traditionen ydermere spredt sig til Vesten. Projektet undersøger hvorledes "Traditionel Islam" og Sufisme i nutiden læres og kommunikeres. Ydermere fokuserer projektet på transmission af "Traditionel Islamisk" religiøsitet og Sufisme fra centre i den traditionelle islamiske verden til resten af verden.

\section{http://pure.au.dk/portal/da/kma@teo.au.dk}

\footnotetext{
${ }^{1}$ Nedenstående artikels analyse skal ses som et kun delvist selvstændigt delelement af min PhD-afhandlings større analytiske sammenhæng. Den samlede afhandling, som endnu er under udarbejdelse, undersøger læringsprocesser og praksis relateret til bearbejdning af selvet inden for rammerne af neo-traditionel islamisk sufisme

${ }^{2}$ Interview med Shukrî som er ansvarlig for de studerende på Dâr al-Mustafa.

${ }^{3}$ Navneændringen blev foretaget på laylat ul-qadr, Ramadan, 2010, og blev indrammet af en større begivenhed med live-transmission fra forskellige lærde, debat om årsagen til og baggrunden for det nye navn og Qiblas fremtidige ambitioner.

${ }^{4}$ Den officielle islamiske licens eller blåstempling til at undervise de overleverede religiøse videnskaber (al-'ulûm alnaqliyya), der videregives fra mester til elev og ideelt går tilbage til profeten.

${ }_{6}^{5}$ Baseret på feltnoter fra navneændringstransmissionen nævnt ovenfor.

${ }^{6}$ Det indledningsvise ritual som kendetegner de fleste sufiordner, hvor murîden officielt lover at følge shaykhens anvisninger.

${ }^{7}$ Interview med 'Umar al-Khatîb, som er en af grundlæggerne af Dâr al-Mustafâ og en af dets mest prominente undervisere.

${ }^{8}$ Profetens sunna, hans handlinger, lære, moral, åndelighed og person i bredeste forstand, opfattes i denne tradition som værende et ikke-reciteret (ghayr matlû) element af åbenbaringen. Han er, med andre ord, en legemliggørelse eller praktisk manifestation af den reciterede åbenbaring, koranen.

${ }^{9}$ Almindeligvis oversættes nafs med ego og defineres som summen af en persons negative tilbøjeligheder og de elementer af mennesket, der leder til at det afholder sig fra eller afviser at adlyde Gud og følge Guds vej.

${ }^{10}$ Interview med informant.

${ }^{11}$ Fra personlige feltarbejdenoter.

${ }^{12}$ Det mest afgørende af disse forbehold er onlinekursets specifikt didaktiske sigte, hvilket medvirker en højere grad af nøgternhed, struktur, detaljer og kompleksitet i materialet, mens de mere performative egyptiske

(C) Forfatteren og Tidsskrift for Islamforskning, ISSN 1901-9580, publiceret 27-4-2012
} 
kassettebåndsprædikener snarere sigter mod at motivere eller mobilisere en religiøs emotionalitet eller gejst, der ideelt set medfører religiøs forandring eller forbedring, end mod at undervise.

${ }^{13}$ Samtale med skandinavisk informant.

${ }^{14}$ Noter fra undervisningen. 